\title{
Quaternary alluvial sedimentation in the Conceição river valley, southeastern Brazil
}

\author{
Sedimentação aluvial quaternária no vale do rio Conceição, sudeste do Brasil
}

\author{
Luiz Fernando de Paula Barros ${ }^{1 *}$, Antônio Pereira Magalhães Junior ${ }^{2}$
}

\begin{abstract}
The aim of this paper is to discuss the first results of the analyses concerning indications of influences of litho structures, tectonics, and climate on the pattern and chronology of Quaternary alluvial sedimentation in the Conceição river valley. This is a mountain tropical area located in the northeastern of Quadrilátero Ferrífero, one of Brazil's most known mountainous domains and one of the world's major iron ore producers. The used methods were based on field research and laboratory analyses of sediments, including optically stimulated luminescence dating. Eight alluvial depositional levels were identified, most of which were morphologically uncharacterized (without the configuration of terraces). Probable river diversion, sediment traps, and tilted blocks indicate the tectonic conditioning on fluvial dynamics, besides the terrace staircases. The formation of cyclic alluvial levels with gravel-bed facies cemented by iron oxideshydroxides could be related to climatic fluctuations. Although data on luminescence dating offer critical information for the understanding of the Quaternary fluvial evolution of the area, several geological and geomorphological inconsistencies require careful analysis. Furthermore, although some ages are consistent with the specific case of the Conceição river, these ages are significantly different to those found in other valleys of Quadrilátero Ferrífero.
\end{abstract}

KEYWORDS: fluvial depositional levels; tectonics; Quaternary paleoclimates; optically stimulated luminescence.
RESUMO: $O$ objetivo deste trabalho é discutir os primeiros resultados da análise dos indícios de influências da litoestrutura, da tectônica e do clima no padrão e na cronologia da sedimentação aluvial quaternária no vale do rio Conceição. Esta é uma área tropical serrana, localizada na porção nordeste do Quadrilátero Ferrifero, um dos mais conhecidos dominios serranos do Brasil e uma das regióes de maior produção de minério de ferro no mundo. Os métodos utilizados foram baseados em investigaçôes em campo e análises laboratoriais de sedimentos, incluindo datação por luminescência opticamente estimulada. Oito niveis deposicionais aluviais foram identificados, sendo que a maioria está morfologicamente descaracterizada (não se configura como terraço). Prováveis desvios fluviais, armadilhas de sedimentos e blocos basculados säo indícios do condicionamento tectônico na dinâmica fluvial da área, além do escalonamento de niveis deposicionais. A formação cíclica de niveis aluviais com sedimentos de leito cimentados por óxidos-hidróxidos de ferro pode estar relacionada a flutuaçóes climáticas. Embora as dataçóes por luminescência ofereçam importantes informaçôes para a compreensão da evolução fluvial quaternária da área, inconsistências geológicas e geomorfológicas demandam que as análises sejam feitas com cautela. Além disso, apesar de algumas idades serem coerentes com o caso do rio Conceição, elas contrastam significativamente em relação às encontradas em outros vales do Quadrilátero Ferrifero.

PALAVRAS-CHAVE: niveis deposicionais aluviais; tectônica; paleoclimas do Quaternário; luminescência opticamente estimulada.

${ }^{1}$ Doutorando em Geografia/Análise Ambiental pelo Programa de Pós-Graduação em Geografia da Universidade Federal de Minas Gerais - UFMG, Belo Horizonte (MG), Brasil.E-mail: luizfpbarros@yahoo.com.br

${ }^{2}$ Professor Associado do Departamento de Geografia da Universidade Federal de Minas Gerais - UFMG, Belo Horizonte (MG), Brasil. E-mail: magalhaesufmg@yahoo.com.br *Corresponding author

Manuscrito ID 29970. Recebido em: 09/05/2013. Aprovado em: 06/08/2013. 


\section{INTRODUCTION}

In humid tropical regions such as Brazil, the nature of quaternary alluvial continental sedimentation is fragmentary and discontinuous in space and time, especially in mountainous areas where streams are marked by repeated geological and geomorphological discontinuities. For such reasons, most quaternary studies in Brazil are restricted to the Atlantic coast based on changes in coastal morphology and sea level; on the other hand, the investigation in inland areas is either underexplored (Stevaux 2000) or it only focuses on large river systems.

Alluvial sequences are often the only evidence of the morphodynamic evolution of an area, thus becoming the record of or the response to denudational and depositional, exogenetic and endogenetic events (Sommé 1990). However, sedimentary records of the humid tropics are often incomplete due to the accelerated geochemical, biogenetic, pedogenetic and geomorphological processes that promote the rapid degradation of alluvial deposits, particularly in tectonically active areas. Despite this effect, such records provide relevant information that is unavailable elsewhere.

In this context, depositional alluvial formations preserved as terraces are only those generated by recent and significant sedimentary events. The oldest fluvial formations are either uncharacterized by erosion or buried by colluvial deposits. Thus, for alluvial sedimentation that does not have a correlation form, the terrace concept is not appropriate and the use of general terms, such as alluvial level and alluvial depositional sequence, is appropriate. A depositional alluvial level (or fluvial level) is a spatiotemporal marker of the river's sediment dynamics, illustrated by its associated depositional sequence. An additional indication could be the fluvial erosive surface; however, its origin should not be taken for structural surfaces conditioned by a rocky substrate or its organization.

Several studies on quaternary fluvial sedimentation have been conducted in Quadrilátero Ferrífero. This is a known geological and geomorphological mountainous domain in the central state of Minas Gerais, Southeastern Brazil. Quadrilátero Ferrífero works as a divider between the great hydrographic basins of the rivers Doce, upper Das Velhas, and upper-middle Paraopeba.

The western part of Quadrilátero Ferrífero has been studied by Marques (1997), and Moreira (1997). This part corresponds to the middle-upper Paraopeba River basin, where those authors present up to five fluvial depositional levels, being the oldest at $80 \mathrm{~m}$ above the modern river. In turn, in the upper Das Velhas River basin, there are generally three fluvial levels. This area is the central part of Quadrilátero Ferrífero, and has been studied by Valadão
\& Silveira (1992), Raposo et al. (2008), Magalhães Jr. \& Saadi (1994), Bacellar et al. (2005), and Magalhães Jr. et al. (2011; 2012). Finally, the eastern part of Quadrilátero Ferrifero is drained by the upper Doce River basin tributaries. In this area, specifically at Caraça River valley, Cherem et al. (2008) found a valley bottom very similar to the one presented in this paper. Maxwell (1972) had also mapped alluvial deposits in this area, but he did not analyze them deeply.

This paper aims to discuss the first results of the analyses on the indications of the influences of lithostructures, tectonics, and climate on the pattern and chronology of the quaternary alluvial sedimentation in the Conceiçáo River valley, a mountain tropical area. Starting from this specific case, it is intended to contribute to the understanding of river dynamics in continental mountain tropical regions during the quaternary.

\section{STUDY AREA}

Quadrilátero Ferrífero ("Iron Quadrangle") is known as one of the world's most important iron ore reserves. In addition, this formation is of great interest for scientific, ecologi$\mathrm{cal}$, and historical research. From a geomorphic perspective, the relief of Quadrilátero Ferrífero can illustrate fluvial responses to tectonic forces in the continental mountainous tropical areas of Southeastern Brazil. Regional relief reflects the spatial distribution of varying lithologic resistance (Alkimin \& Marshak 1998, Salgado et al. 2007, Varajão et al. 2009) with soft rocks, such as schist and phyllite, alternating with hard rocks, such as quartzite and itabirite (laminated, metamorphosed iron formation of iron oxides - hematite, magnetite, martite - abundant in quartz, but very rarely containing mica and other accessory minerals, Dorr \& Barbosa 1963). Structural conditioning is also very important for the evolution of this landscape. Quadrilátero Ferrífero is cut by major faults and folds that were eroded, resulting in inverted anticlines and synclines (Dorr 1969).

The ridged borders of Quadrilátero Ferrífero are supported by the more resistant to weathering rock formations of the Minas Supergroup: itabirites and quartzites of the Paleoproterozoic $(2.58$ - 2.04 Gy - Hartmann et al. 2006). In turn, intermediate relief compartments have developed in the Das Velhas River Supergroup rocks, a geological greenstone belt unit containing schists, greywackes, quartzites, and conglomerates of the Archaean (2.76 Gy Hartmann et al. 2006). The crystalline basement, composed of granites, gneisses, and migmatites, was exhumed between the supracrustal rocks in the central and lower portions of the region. Generally, the basement is related to regional 

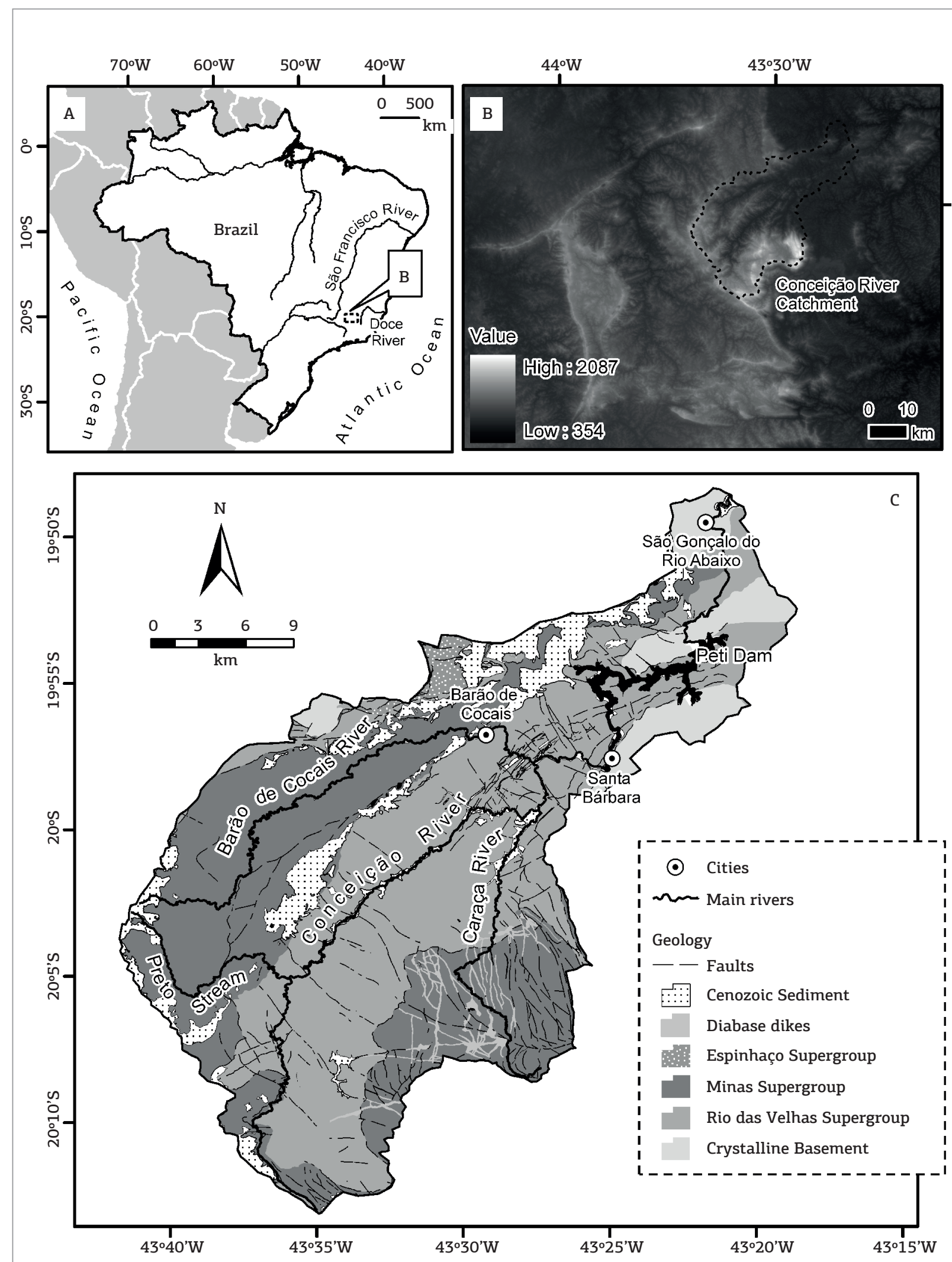

Figure 1. (A) Localization of the Quadrilátero Ferrífero in Brazil; (B) digital elevation model of the Quadrilátero Ferrífero and catchment localization of the Conceição River; (C) catchment geology of the Conceição River. Geologic data source: Lobato et al. (2005). 
Archaean domic structures (Alkmim \& Marshak 1998). Its weak and weathered rocks generate a landscape of smoothed hillslopes.

Tectonics plays a central role in the Quadrilátero Ferrífero's relief. Most of the faults that have been identified in the region were generated in Precambrian orogenic cycles. However, the opening of the South Atlantic Ocean and the W - NW migration of the South American Plate caused an intraplate transfer of tectonic stress, leading to the reactivation of ancient faults (NW - SE and NE - SW) and the generation of recent faults (E - W) (Hasui 1990, Saadi 1993, Saadi et al. 2005). As a result, several studies have identified Cenozoic tectonic effort in the region of Quadrilátero Ferrífero, including instances of drainage incision during the quaternary and tectonic deformations in unconsolidated sediments (Saadi 1991, Saadi 1993, Magalhães Jr. \& Saadi 1994, Marques 1997, Moreira 1997, Sant'Anna et al. 1997, Lipski 2002, Bacellar et al. 2005, Campos 2006, Raposo et al. 2008, Varajáo et al. 2009, Lana \& Castro 2010, Magalhães Jr. et al. 2011, 2012).

The Conceição River valley is located in northeastern of Quadrilátero Ferrífero (Fig. 1) at the so called Conceição Anticline (Dorr 1969), which is an eroded antiformal structure situated between the Gandarela Syncline and the Caraça Ridge (Fig. 2). The Conceição River is approximately $90 \mathrm{~km}$ long with a sixth-order drainage basin of approximately $790 \mathrm{~km}^{2}$. The river valley is almost entirely carved in rocks from the Das Velhas River Supergroup; however, important headwater areas exhibit rocks from the Minas Supergroup, and the river flows on the crystalline basement in the lower course. The Conceição River catchment also contains outcrops of the Espinhaço Supergroup, comprised of Mesoproterozoic quartzite and sericitic quartzite, as well as diabase dikes that fill several ancient faults in the upper basin of the Caraça River, which is the main tributary in the right bank. These diabase dikes exert significant control over the drainage pattern of the sub-basin. It is noteworthy that the Conceição River basin is affected by two major fault systems: Fundão-Cambotas and Água Quente, being the latter responsible for the superimposition of the basement rocks on the supracrustal rocks.

According to the Köppen climate classification, the area's climatic designation in higher elevations is Cwb, indicating tropical in high areas with summer rains and cool summers, and Cwa in lower elevations, indicating tropical in high areas with summer rains and hot summers. The mean annual rainfall rates are around $1,400 \mathrm{~mm}$, being the months from October to March the wettest, and the period between May and September relatively dry. The mean annual temperature is $21.7^{\circ} \mathrm{C}$. The remnants of native vegetation are composed of grasslands, or campos (in rocky outcrops and higher elevations), and semideciduous forests and transition areas for savanna-like vegetation or cerrado.

\section{METHODS}

Field research was conducted by collecting data from alluvial profiles and analysis of their spatial context in the valley. Depositional facies were described according to their organization or sequence; grain size, such as clay, silt, sand, or gravel; thickness; and transition type, such

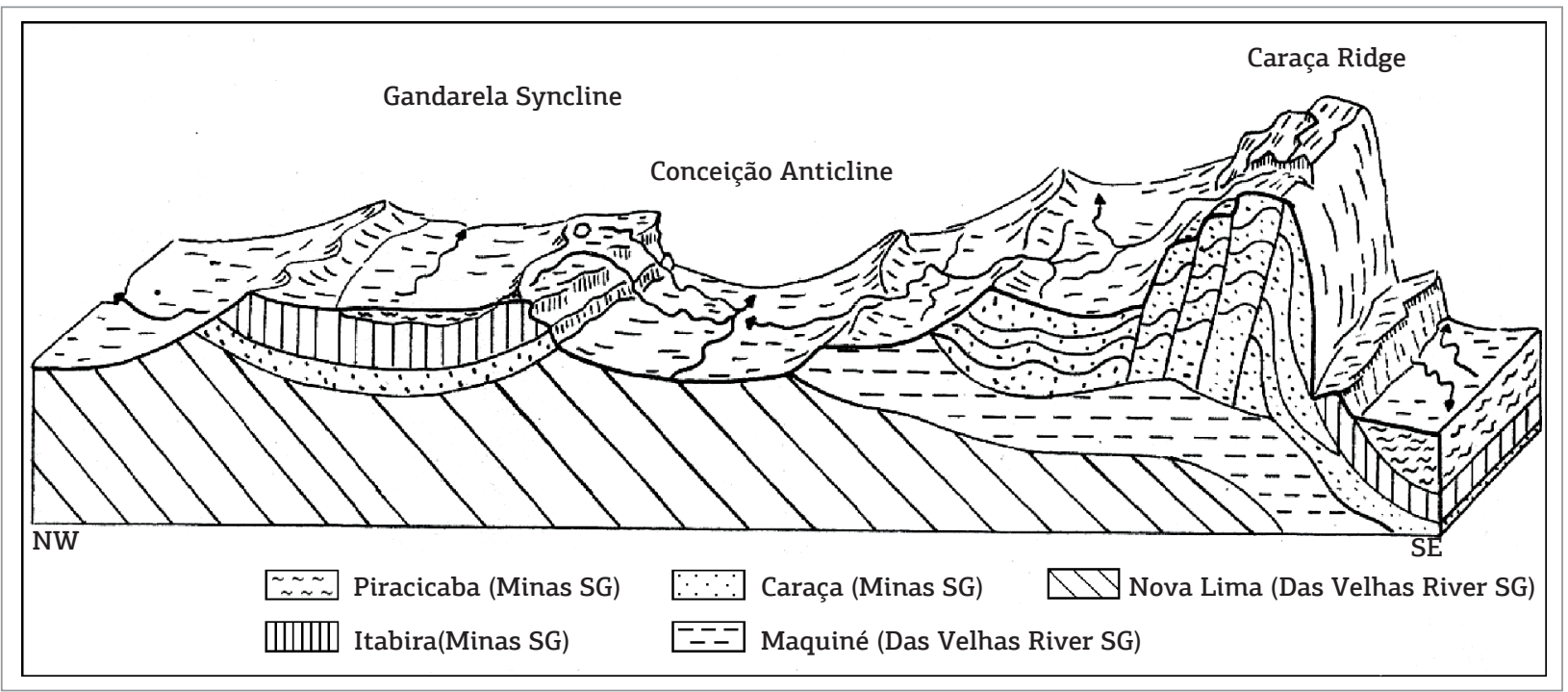

Figure 2. Scheme of the eroded antiformal structure of the Conceição Anticline (Barbosa \& Rodrigues 1967, modified). 
as gradual or abrupt. In addition, the presence or absence of sedimentary structures, organic matter, cementation by iron oxides-hydroxides, and bioturbation was considered. Gravels were described according to average size, petrography, roundness, and type of associated matrix.

Depositional alluvial levels were identified based on the correlation of data concerning the altitude of the deposit's base, obtained by a GPS receptor; its relative position to the modern channel (gap between the depositional level and the current river bed), estimated in field study; as well as level type, such as cut-in-bedrock, fill, or nested fill; and sequences of facies. Fluvial levels were represented in longitudinal and transverse distributions, and were characterized in synthetic profiles. These profiles represent a summary of all sections relating to a specific depositional level, thus reflecting a superposition of data.

Among the set of alluvial sequences of each depositional level, a more accurate representative profile was chosen to collect samples for laboratorial dating and granulometric analysis. Many of the sequences include only gravel-bed facies and are often cemented by iron oxides-hydroxides, which prevented sampling in some cases. Because of these limitations, it was not possible to collect samples of deposits in a same cross-section of the valley. Fine sediments were classified by a standard grain size analysis carried out in the Geomorphology Laboratory at the Universidade Federal de Minas Gerais. From the gravel-bed facies, 100 clasts were randomly collected for the measurement of size, including width and length, and for the definition of lithology and roundness.

Sediment samples were collected from natural exposures or trenches for optically stimulated luminescence (OSL) dating. Under a light-proof tarp, PVC tubes of $5 \mathrm{~mm}$ in diameter and $30 \mathrm{~cm}$ in length were inserted into sandy layers at lower facies of alluvial sequences in order to collect samples. The tops of the sediment sequences were significantly altered during the Quaternary by geomorphological processes. Samples were prepared and analyzed at Datação, Comércio e Prestação de Serviços laboratory, in São Paulo, by the Multiple Aliquot Regenerative-dose (MAR) protocol. Although more accurate methods are available, the MAR protocol is sufficient for obtaining reliable ages of sediments from the early and middle Holocene and late Pleistocene, even for alluvial deposits (Jain et al. 2004).

All procedures were conducted under low-intensity red light. Material was extracted from the central part of the sample tubes, and quartz grains $(88-180 \mu \mathrm{m})$ were separated after treatment with $\mathrm{H}_{2} \mathrm{O}_{2}(20 \%), \mathrm{HF}(20 \%)$, and $\mathrm{HCl}(10 \%)$, in addition to drying and sieving. For the analysis of cumulative dose, the TL/OSL Automated Systems, Model 1100-series Daybreak Nuclear Instruments, Inc was used. Annual dose measurements were conducted with the Canberra Inspector Portable Spectroscopy Workstation (NaI - Tl).

\section{RESULTS}

Eight alluvial levels were identified in the Conceição River valley (Tab. 1, Fig. 3). The youngest level (L1) corresponds to the modern river regime. The second one (L2) topographically corresponds to the floodplain; however, only its facies of fines remain being deposited. The third (L3) is the only level that can still be characterized as a fluvial terrace in various segments of the valley because of its morphological preservation. The older levels (L4 to L8) occur along the hillslopes and are morphologically uncharacterized, that is, they do not show a terrace form.

The three oldest depositional levels were classified as unpaired because they were found only in the right valley flank. However, these levels could be originally

Table 1. Summary of main depositional level characteristics

\begin{tabular}{l|c|c|c|c}
\hline Level & Type & Valley distribution & Altitudes & $\begin{array}{c}\text { Gap for the modern } \\
\text { river }\end{array}$ \\
\hline L1 & Nested fill & Paired & $787-574 \mathrm{~m}$ & $0 \mathrm{~m}$ \\
\hline L2 & Nested fill & Paired & $882-770 \mathrm{~m}$ & $0 \mathrm{~m}$ \\
\hline L3 & Fill & Paired & $794-640 \mathrm{~m}$ & $0 \mathrm{~m}$ \\
\hline L4 & Cut-in-bedrock & Paired & $724-582 \mathrm{~m}$ & $7 \mathrm{~m}$ \\
\hline L5 & Cut-in-bedrock & Paired & $817-730 \mathrm{~m}$ & $17 \mathrm{~m}$ \\
\hline L6 & Cut-in-bedrock & Unpaired & $758-766 \mathrm{~m}$ & $38 \mathrm{~m}$ \\
\hline L7 & Cut-in-bedrock & Unpaired & $779 \mathrm{~m}$ & $50 \mathrm{~m}$ \\
\hline L8 & Cut-in-bedrock & Unpaired & $788-777 \mathrm{~m}$ & $56 \mathrm{~m}$ \\
\hline
\end{tabular}




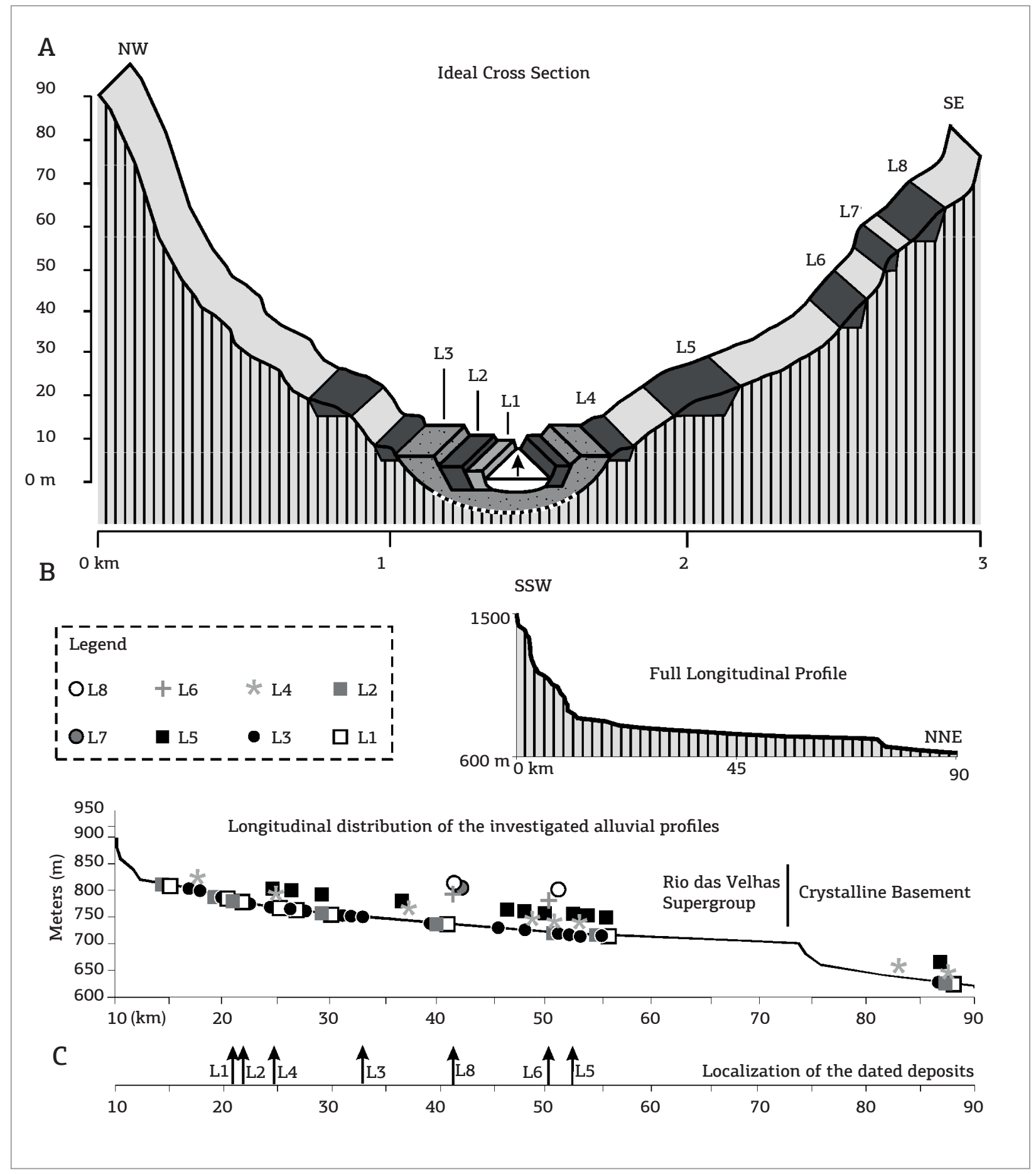

Figure 3. (A) Idealized cross section of the depositional levels; (B) longitudinal distribution of the investigated alluvial profiles; and $(C)$ longitudinal distribution of the dated deposits.

paired levels that have been eroded, buried by colluvial deposits, or simply concealed by dense vegetation in several areas. In addition to natural deposit dismantling, anthropic disassembly due to historical mining activities in the region must be considered. In turn, the two younger levels (L1 and L2) were classified as nested fill because they were formed into L3 deposits. In other words, the river did not carve the rocky substrate before the L2 and L1 formations.

The depositional sequence was characterized based on the synthetic profiles shown in Fig. 4. Figure 5 shows the localization of the photos presented in the text. Representative images of the identified fluvial levels are shown in Figs. 6 and 7. Results from the analyses of grain 


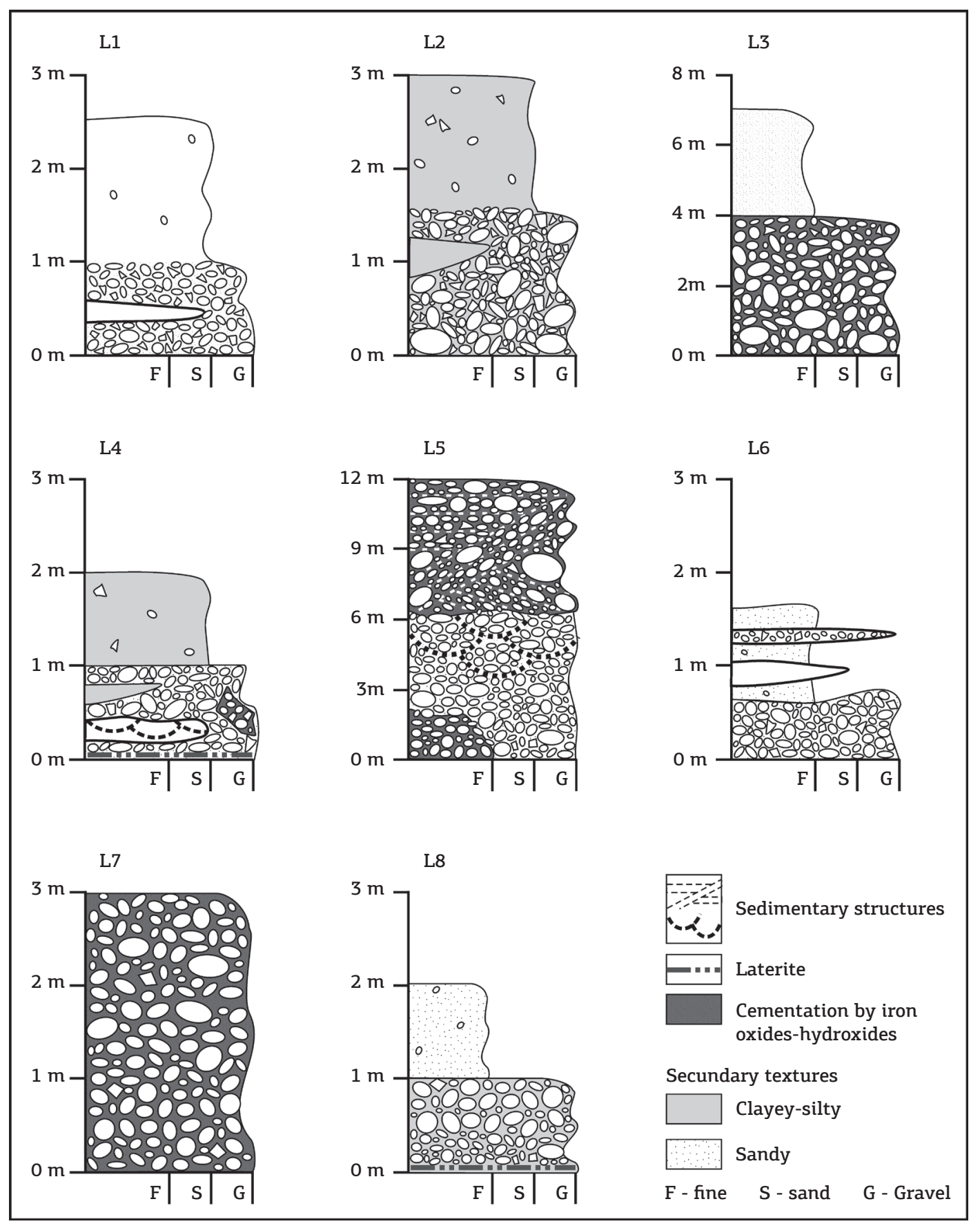

Figure 4. Synthetic profiles of depositional levels.

size for materials $<2 \mathrm{~mm}$ and morphometric attributes for gravels are presented in Tab. 2.

In general, alluvial sequences exhibit well-rounded, supported hematite gravels. The finest facies are generally homogeneous, slightly thick, and affected by surficial processes. Sedimentary structures are locally found in sandy and gravel facies. Multiple alluvial profiles exhibit gravel layers cemented by iron oxide-hydroxides or laterite formation.

OSL dating results are arranged in Tab.3. The L 4 and L5 ages appear to be the most reliable ones among the obtained results. The sampled material in these river levels was almost entirely composed of quartz grains, which formed the basis of the OSL dating method. Moreover, the 


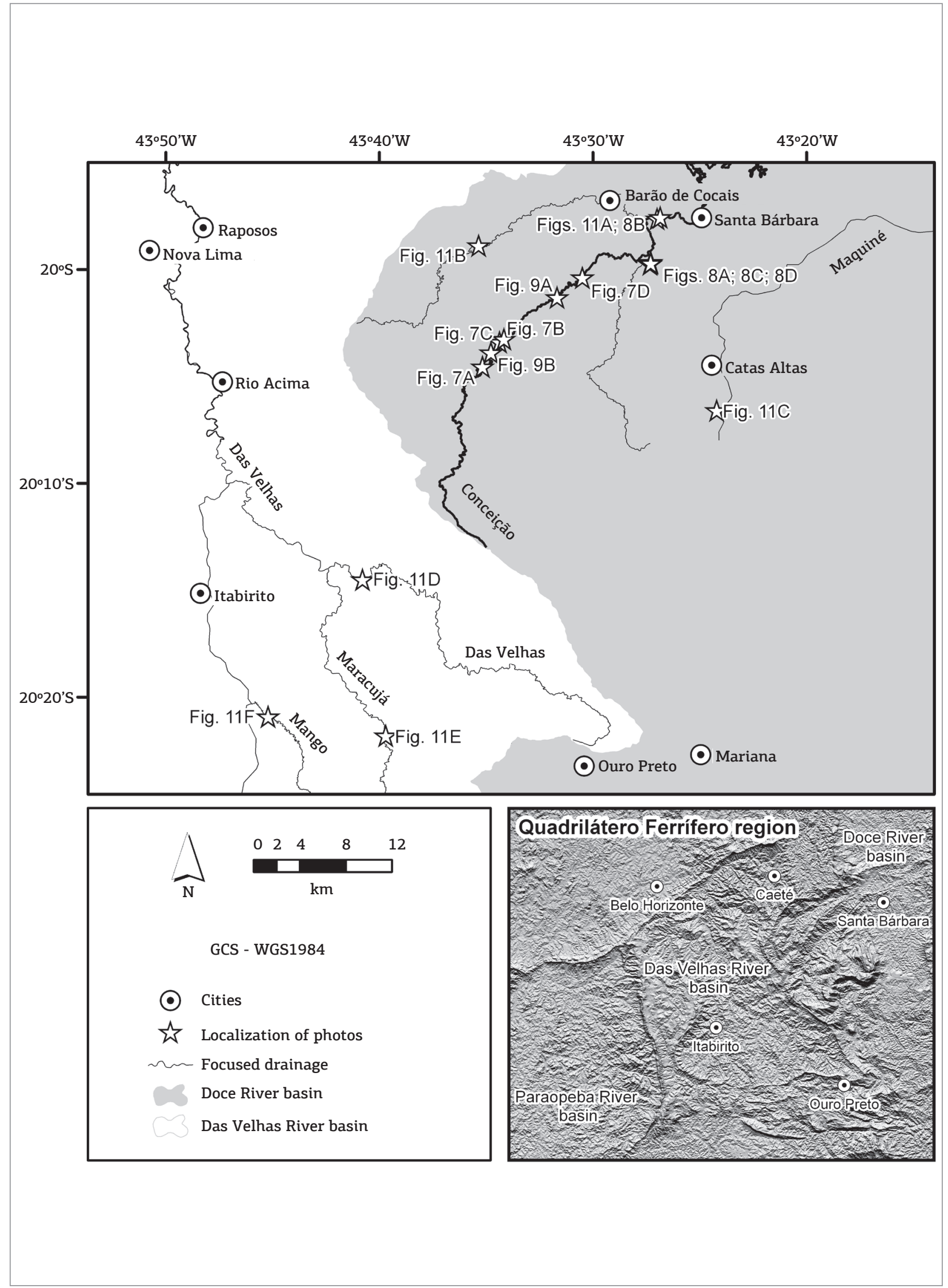

Figure 5. Localization of the photos presented in the text. 

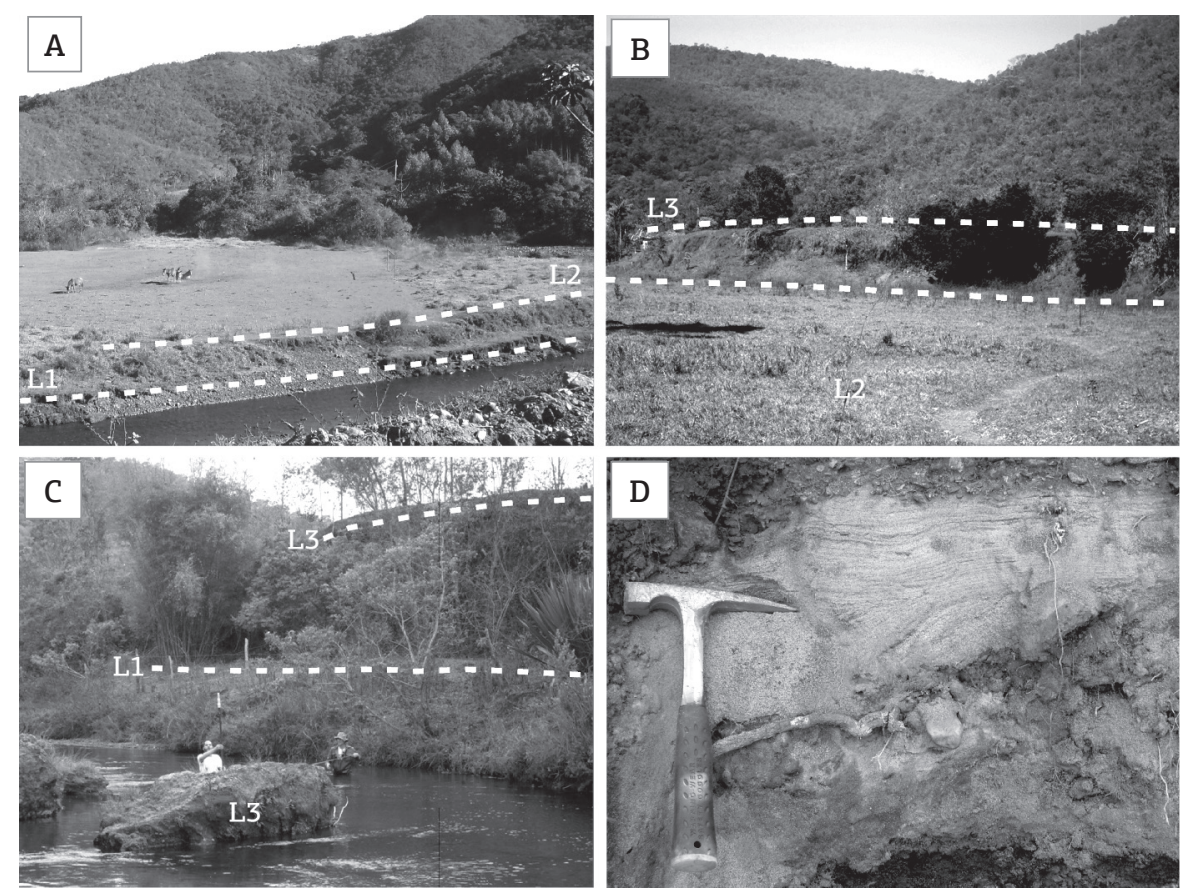

Figure 6. Photographic images of younger alluvial levels. (A) The contact between L1 (spatially restricted) and the consolidated floodplain, L2; (B) The contact between L2 and L3; (C) The contact between L1 and L3, note the presence of residual L3 sediments in the actual river bed; (D) Sedimentary structures in a L4 deposit showing its good preservation.

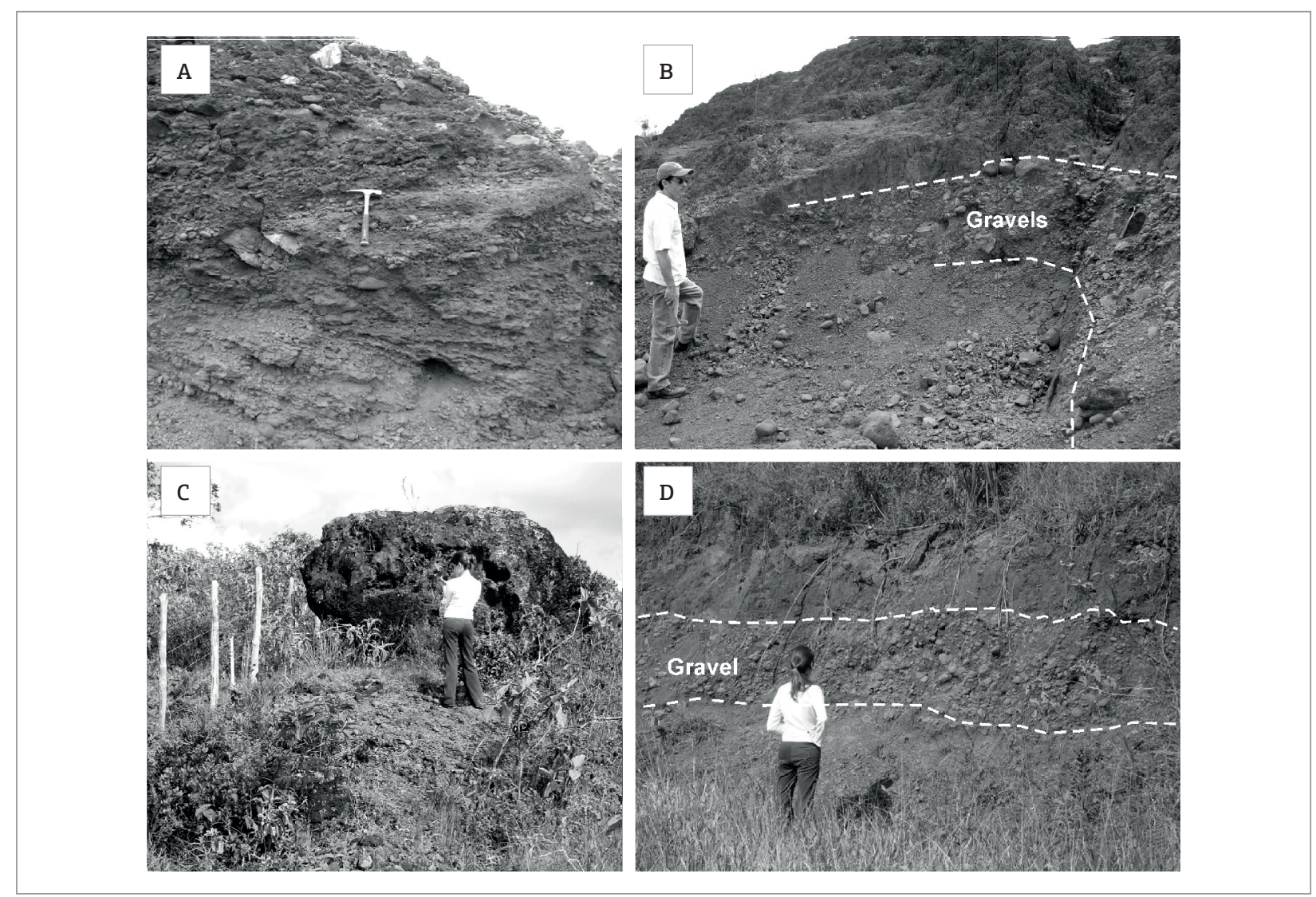

Figure 7. Photographic images of the older alluvial levels or depositional sequences. (A) Sedimentary structures in a L5 deposit, preserved due to cementation by iron oxides-hydroxides; (B) Expression of a L6 deposit (river bed facies highlighted); (C) Remaining L7 deposits; (D) Expression of a L8 deposit (river bed facies highlighted). 
Table 2. Summary of sedimentological characteristics of a depositional level representative section ${ }^{a}$

\begin{tabular}{|c|c|c|c|c|c|c|c|c|c|}
\hline \multirow{2}{*}{ Facies } & \multirow{2}{*}{\multicolumn{2}{|c|}{ Attributes }} & \multicolumn{7}{|c|}{ Depositional Level } \\
\hline & & & L1 & L2 & L3 & L4 & L5 & L6 & L8 \\
\hline \multirow{4}{*}{ Fine } & \multicolumn{2}{|c|}{ Clay dispersion in water (\%) } & 1 & 1,2 & 6,8 & 0,2 & - & 0,1 & 0,3 \\
\hline & \multirow{3}{*}{$\begin{array}{l}\text { Grain size } \\
(\%)\end{array}$} & Clay & 5 & 7 & 30 & 27 & - & 27 & 55 \\
\hline & & Silt & 37 & 59 & 39 & 26 & - & 36 & 15 \\
\hline & & Sand & 58 & 34 & 31 & 47 & - & 37 & 30 \\
\hline \multirow{17}{*}{ Gravel } & \multirow{3}{*}{$\begin{array}{l}\text { Length } \\
(\mathrm{cm})\end{array}$} & Major & 10 & 42 & - & 10 & 18 & 9 & 20 \\
\hline & & Minor & 1,5 & 2 & - & 1,5 & 0,5 & 2,5 & 1,5 \\
\hline & & Mean & 3,9 & 7,2 & - & 4,8 & 5,6 & 4,8 & 5,6 \\
\hline & \multirow{5}{*}{$\begin{array}{l}\text { Roundness } \\
(\%)\end{array}$} & Well rounded & 4 & 3 & - & 13 & 22 & 3 & 5 \\
\hline & & Rounded & 26 & 14 & - & 37 & 35 & 23 & 21 \\
\hline & & Subrounded & 33 & 32 & - & 14 & 36 & 42 & 37 \\
\hline & & Subangular & 30 & 35 & - & 29 & 7 & 22 & 30 \\
\hline & & Angular & 7 & 5 & - & 7 & - & 10 & 7 \\
\hline & \multirow{9}{*}{$\begin{array}{l}\text { Petrography } \\
(\%)\end{array}$} & Itabirite & 59 & 41 & - & 62 & 31 & 34 & 18 \\
\hline & & Hematite & 26 & 22 & - & 27 & 38 & 32 & 2 \\
\hline & & Quartz & 6 & 1 & - & 3 & 16 & 22 & 80 \\
\hline & & Quartzite & 3 & 4 & - & - & 4 & - & - \\
\hline & & Ferruginous Quartzite & 5 & - & - & - & 9 & 1 & - \\
\hline & & Phyllite & - & 20 & - & 5 & - & 7 & - \\
\hline & & Schist & - & - & - & 1 & 2 & 3 & - \\
\hline & & Laterite & - & 3 & - & - & - & - & - \\
\hline & & Unidentified & 1 & 9 & - & 2 & - & 1 & - \\
\hline
\end{tabular}

${ }^{a}$ Cementation by iron oxides-hydroxides prevented analysis of L3 and L7 gravels.

Table 3. Concentrations of Thorium (Th), Uranium (U), and Potassium (K) in the samples in addition to annual and cumulative doses and age

\begin{tabular}{l|c|c|c|c|c|c}
\hline Level & Th (ppm) & U (ppm) & K (\%) & $\begin{array}{c}\text { Annual dose } \\
(\boldsymbol{\mu} \text { Gy/year) }\end{array}$ & $\begin{array}{c}\text { Cumulative } \\
\text { dose (Gy) }\end{array}$ & Age (ka) \\
\hline L1 & $2.95 \pm 0.11$ & $1.41 \pm 0.15$ & $0.09 \pm 0.01$ & $876 \pm 60$ & - & - \\
\hline L2 & $4.81 \pm 0.17$ & $2.42 \pm 0.46$ & $1.42 \pm 0.21$ & $2,641 \pm 343$ & 4.96 & $1.9 \pm 0.3$ \\
\hline L3 & $4.89 \pm 0.18$ & $1.71 \pm 0.36$ & $0.19 \pm 0.03$ & $1,207 \pm 134$ & 92.9 & $77 \pm 12.4$ \\
\hline L4 & $1.04 \pm 0.04$ & $0.68 \pm 0.06$ & $0 \pm 0$ & $455 \pm 18$ & 46.0 & $101.2 \pm 9$ \\
\hline L5 & $2.13 \pm 0.08$ & $1.22 \pm 0.28$ & $0 \pm 0$ & $675 \pm 77$ & 114.3 & $169.5 \pm 27.9$ \\
\hline L6 & $6.38 \pm 0.23$ & $2.23 \pm 0.64$ & $0.06 \pm 0.01$ & $1,315 \pm 190$ & 110.13 & $83.8 \pm 16.3$ \\
\hline L8 & $2.84 \pm 0.10$ & $1.03 \pm 0.04$ & $0.12 \pm 0.02$ & $806 \pm 36$ & 112.28 & $139.3 \pm 13.2$ \\
\hline
\end{tabular}

presence of depositional structures indicates the high degree of preservation for these deposits.

\section{DISCUSSION}

\section{Implications of the deposits' composition}

Except for L8, the alluvial sequences show the clear predominance of itabirite and hematite gravels, which may represent more than $80 \%$ of the samples (Tab. 2). Part of this material was likely originated from a particular type of silica-poor $(<5 \%)$ banded iron formation that is present in Quadrilátero Ferrífero, being designated as hard hematite by Dorr (1965).

The high erosion of itabirites and hard hematite formations appears to be connected to the relief evolution through differential erosion in the area. From the measurement of the production of cosmogenic isotope ${ }^{10} \mathrm{Be}$ in the upper Das Velhas River catchment, Salgado et al. (2007) show that highlands, which are supported by quartzites, itabirites, and Cenozoic canga, are extremely resistant to vertical lowering 
of relief, with erosion rates between 1.71 and $2.58 \mathrm{~m} \mathrm{Ma}^{-1}$. However, this lithology exhibits distinct fragility to the lateral retraction of hillslopes, with erosion rates between 12.71 and $14.60 \mathrm{~m} \mathrm{Ma}^{-1}$. Such fragility is associated with the erosion of the weaker schists, phyllites, and granite-gneisses that essentially constitute the escarpment base.

This process is particularly apparent in hillslopes of the Gandarela Syncline in the Conceição River valley, since the hillslopes from the Caraça Ridge exhibit lithologic homogeneity. The high erosion potential in basins that lie within the anticline in relation to basins that drain the interior of the Gandarela Syncline would have led to the capture of the Preto Stream, which was originally a tributary of Barão de Cocais River (the major left bank tributary of the Conceição River). According to Fabri et al. (2008), the incision of that stream over an ancient thrust fault would have led to the opening of a canyon and would have been facilitated by the outcrop of the fragile dolomites from the Gandarela Formation (Itabira Group/Minas Supergroup).

The dominance of quartz gravels in L8 (Tab. 2) appears to indicate that the analyzed record is probably related to a confluence area between the rivers Caraça and Conceição. The Conceição River would provide itabirite and hematite gravels (20\%), and the quartz gravels (80\%) would come from the Caraça River. The quartzite, prevalent in the Caraça River catchment, would not support the transport, disintegrating in the sandy fraction.

On the other hand, Moreira (1997) and Marques (1997) also describe probable alluvial deposits of up to $100 \mathrm{~m}$ above those of modern rivers with a small amount of itabirite gravels in contrast with the recent alluvial levels in the middle-upper Paraopeba River catchment, western Quadrilátero Ferrífero. This finding may suggest that these fluvial levels may be, including L8, markers in the process of post-Pliocene relief inversion at Quadrilátero Ferrífero (Medina et al. 2005), which would have favored itabirite scarp dissection.

The high degree of roundness in the gravels shows the efficiency of fluvial transport for the erosion of sediments. This particular mechanism is a result of the high energy of mountain rivers in the region of Quadrilátero Ferrífero, as wel as of the chemical erosional power of their tropical waters. However, there is a significant amount of sediments accumulated along the valley. Detrital sediment loads are particularly abundant and may have led to the retardation of vertical fluvial incision. In its most recent dynamics, the Conceição River incision was slowed down by sediments from L2 and L3. In the first case, gravels are larger than the average gravels transported by current stream power, and might be likely to move during significant floods (Fig. 8A). In the case of L3, its basal facies are cemented by iron oxides-hydroxides, forming a shield that is resistant to fluvial erosion. Unable to carve the bedrock, the river tends to laterally erode the deposits, further exposing the detrital material paving the river bed (Fig. 8B).

The youngest alluvial sequence is marked by the dominance of a sandy fraction (Tab. 2). This sequence is probably connected to human occupation in the area since the $18^{\text {th }}$ century. Initially focused on deposits from river beds and lower terraces, several environmental impacts caused by gold mining have been reported in the region. This activity led to increasing sediment supplies (Martins 1994). Recently, the effects of iron mining and eucalyptus monoculture have aggravated this situation because of their direct interference on headwaters and aquifer recharge areas. In addition, changes in concentrations of several geochemical elements, such as zinc, copper, and arsenic in water and sediments of the Conceição River were reported by Parra (2006) as the effects of modern mining activities.

Medina et al. (2005) determined that the impacts from anthropogenic changes on the regional landscape may have been aggravated by the regional tropical climatic characteristics. The strong rainfall seasonality is a factor that favors morphogenesis due to the heavy runoff on steep slopes, often not covered by vegetation.

\section{Considerations about the obtained ages}

Taking the $\mathrm{L} 4$ age as a reference, the downcutting rate between L8 and L4 was approximately $1.28 \mathrm{~mm} \mathrm{a}^{-1}$. The age obtained for L6 would be inconsistent for being lower than that obtained for L4. The downcutting rate between L5 and L4 would be of approximately $0.14 \mathrm{~mm} \mathrm{a}^{-1}$.

Bridgland \& Westaway (2008) analyzed terrace staircases in various regions throughout the world and reported downcutting rates between 0.03 and $0.2 \mathrm{~mm} \mathrm{a}^{-1}$ for the outer regions of Archean cratons. Only a few papers present alluvial deposit dating by OSL in Southeastern Brazil (Tatumi et al. 2003, Tatumi et al. 2006, Sallun \& Suguio 2007). Generally, these reports do not show downcutting rates, nor do they provide adequate data for estimation. In other valleys in Quadrilátero Ferrífero, recent surveys indicate downcutting rates close to those obtained in the Conceição River valley in the L5-L4 period. In the Maracujá River valley, rates vary between 0.090 and $0.165 \mathrm{~mm} \mathrm{a}^{-1}$ (Magalhães Jr. et al. 2012). These rates are expected to be higher in the upper Das Velhas River valley, with values between 0.200 and $0.600 \mathrm{~mm} \mathrm{a}^{-1}$ (Magalhães Jr. et al. 2011). A comparison of these values indicates that the L8 age was underestimated since it is lower than L5, and because it provides a significantly high downcutting rate, incompatible with the tectonic setting of the area. 

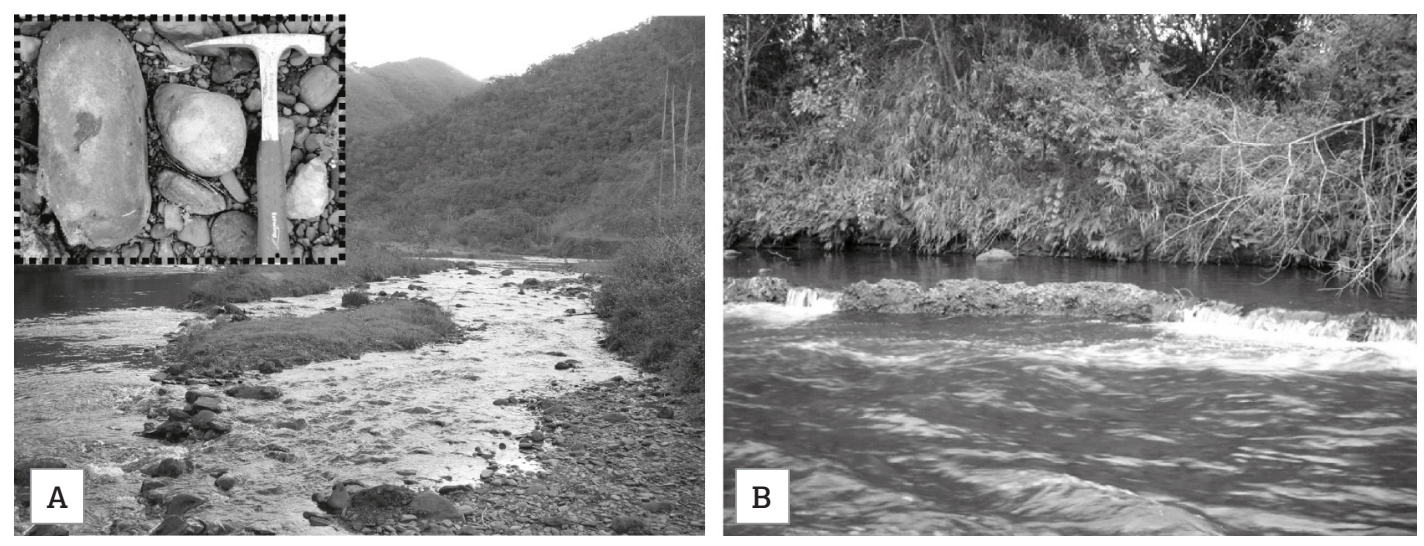

Figure 8. (A) L2 large pebbles exposed by the upper fine facies river erosion; (B) L3 riverbed gravels cemented by iron oxides-hydroxides forming a shield that is resistant to fluvial erosion.

Three hypotheses can be formed to interpret the detected distortions in the dating of some alluvial sequences: (i) the abundance of iron in the area; (ii) surficial alteration; and (iii) the type of sedimentary transport prior to deposition.

As noted by laboratory tests and indicated in literature, in general the presence of accessory minerals, such as iron oxides, provides overestimated ages (Murray \& Olley 2002). This scenario is apparent for samples L3, L4, and L5, which were analyzed with two separate cleaning processes. This procedure yielded the most reliable ages, considering the location and ages of other levels. The first obtained results to these samples were $131 \pm 21 \mathrm{ka}, 262 \pm 23 \mathrm{ka}$, and $231 \pm 38 \mathrm{ka}$, respectively.

It is possible that the ages from L6 and L8 were underestimated, which may be connected to surficial processes (pedogenesis, bioturbation, erosion, colluvium) that could have promoted sediment mixing and changes in material behavior and characteristics. Some alteration may be indicated by the water dispersible clay results in fine facies (Tab. 2). The value obtained for L3 sediments is significantly higher than those of the other samples. In older levels, the more readily erodible material was probably washed away. In L1 and L2, however, the low water dispersible clay content may be connected to the major presence of organic matter which stabilized the material. L3 was the only sample collected with depth exceeding $1 \mathrm{~m}$ to avoid pedogenetic material. For the older levels, datable material, when present, was only $1 \mathrm{~m}$ thick. Furthermore, it is possible that the fines facies were removed, enabling colluvial material to cover the riverbed gravels.

In turn, the L2, L6, and L8 ages may have been underestimated because of the type of sedimentary transport prior to deposition. The dominance of finer sediments indicates that the deposition was achieved by flux with high turbidity, which may have led to the partial bleaching of quartz grains (Jain et al. 2004).

For L1 sediments, despite sand abundance, the failure of dating was somehow expected since very recent sediments (less than a thousand years old) are more susceptible to partial bleaching, as shown by Jain et al. (2004). According to the laboratory, the result of the L1 sample analysis is not reproductive, since it presents an OSL signal of inconstant intensity. Thus, it is not possible to find a mean age because the level of uncertainty is too high.

Besides the specific problems already pointed out, some general restrictions to OSL dating can also be considered for the area. As related by Kock et al. (2009), there are two major problems in dating fluvial sediments by OSL. The first one is related to the absence of suitable sand layers, especially in high fluvial energy regimes of mountainous areas. In general, a $60 \mathrm{~cm}$ layer is desirable, because a $30 \mathrm{~cm}$ radius sets the volume that will contribute with most of the radiation received by the sample. The second one is related to the upper dating limit of OSL, which should be, in theory, of several $100 \mathrm{ka}$. However, this limit is highly dependent on the radioactive dose rate in any particular setting.

In sediments that are rich in radioactive elements, as observed in granitic areas, the saturation dose of the OSL signal may be reached in about $200 \mathrm{ka}$, or even less (Burbank \& Anderson 2001, Kock et al. 2009). As observed in Tab. 3, samples of L5, L6 and L8 have a very similar cumulative dose (110 - 115 Gy). This can suggest the upper limit of saturation to quartz in the region. Therefore, the obtained ages must be considered as minimum ages, 
which make the results more significant. In spite of that, the laboratory responsible for our analysis insists on an upper dating limit of OSL of 1,000 ka, which implies in a maximum cumulative dose of 1,000 Gy.

\section{Probable tectonic/structural conditioning}

Several indications of structural and tectonic conditioning in the morphodynamic evolution of the Conceição River valley were identified and stand out due to a set of anomalies in the confluence area of rivers Barão de Cocais and Caraça with the Conceição River. In this stretch, the Conceição River, which is generally NE-SW oriented, abruptly changes its course several times (Fig. 9). In the same area, the Barão de Cocais River also changes its direction before its confluence with the Conceição River. A rather broad valley projects the probable continuity of Barão de Cocais River prior to such direction changes. However, this valley has no significant drainage channel, suggesting that it was sculpted by the Barão de Cocais River and later abandoned. Alluvial records were not found in this abandoned valley; only a significant colluvium deposit was observed near the entrance of the city of Barão de Cocais. However, this deposit contains some alluvial gravels, and sediments are cemented by iron oxides-hydroxides, probably indicating past valley bottom conditions.

Alluvial profiles observed at the midcourse suggest the activity of tectonic/structural sediment traps along the river valley. These features may be related to a tectonic regionally distensive context described by Sant'Anna et al. (1997) in the sedimentary Basin of Fonseca (near Catas Altas, Doce River catchment) that was responsible for faults in Quaternary lateritic covers. A distensive tectonic regime NW (NW)-SE (ESE) was also
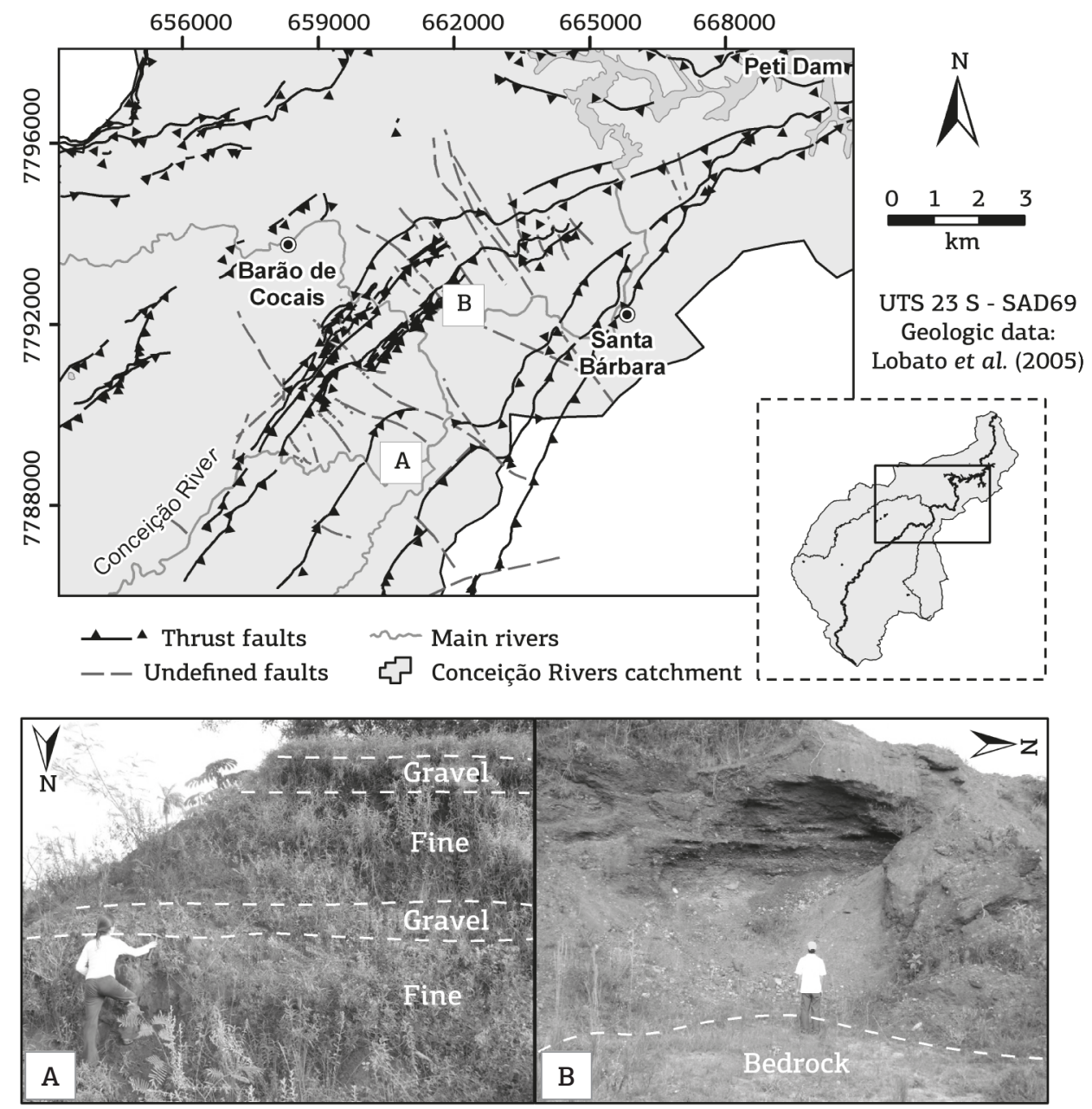

Figure 9. Abrupt river diversions and probable sediment traps along the middle Conceição River valley indicating strong structural and neotectonic conditioning on the fluvial dynamic. 
recorded in other areas of Southeastern Brazil, occurring from the late Pleistocene to the early Holocene (Riccomini 1989, Salvador 1994, Mello 1997, Sarges 2002, Silva \& Mello 2011).

The first sediment trap (Fig. 9A) occurs near the confluence with the Caraça River, indicated by significant sediment accumulation. Some profiles in this area are characterized by a succession of fine and coarse sediments which show the continuous stacking of alluvial sequences, since is typical in subsidence areas. The characteristics and context of this profile suggest a temporal association with L3. The second trap takes place downstream to the confluence with Baráo de Cocais River (Fig. 9B). In this area, alluvial profiles more than $12 \mathrm{~m}$ thick were observed, showing a significant gravel accumulation, which is abnormal in relation to the other analyzed profiles. Because of its sedimentary characteristics and its vertical position in the valley, this deposit may be temporally associated with L5.

Downstream, the geological mapping of the area near São Gonçalo do Rio Abaixo through CPRM (2005) indicates ancient faults or compressional shear zones with high block at ESE or SE. In the same area, the Conceição River inflects to the opposite high block direction, at the right bank. In this section, more significant fluvial deposits were observed only in this bank. Considered altogether, these facts may suggest tilting in the area, as proposed by the regional morphoneotectonic mapping of the Doce River catchment conducted by Souza (1995).

It is remarkable that the main anomalies in the stream gradient index identified by Barros et al. (2010) for Conceição River are mainly located at the upper course and are closely related to ancient tectonic structures, which suggests possible recent reactivations. These assemblages of geological and geomorphological indications point to significant neotectonic activity in the area. This neotectonic conditioning uses structures inherited from Precambrian tectonic events and would also be responsible for the formation of new structures. Previous research points out to several other indicators and evidence of Cenozoic tectonic movements in the Doce River catchment (Saadi 1991, Suguio \& Kohler 1992, Saadi 1993, Souza 1995, Mello 1997, Sarges 2002, Saadi et al. 2005) and in Quadrilátero Ferrífero, as previously stated.

In addition to these indications, the major evidence of a positive neotectonic influence on the morphodynamic evolution of Conceição River valley is presented in the staircase character of the river levels. In several studies concerning the evolution of river valleys in Quadrilátero Ferrífero, river level staircases have been treated as continuous responses to the Brazilian Shield uplift associated with tectonic block differential activity (Magalhães Jr. \& Saadi 1994, Marques 1997.
Moreira 1997, Cherem et al. 2008, Raposo et al. 2008, Magalhães Jr. et al. 2011, 2012).

\section{Probable climatic conditioning}

After analyzing terrace staircases worldwide, Bridgland $\&$ Westaway (2008) proposed that this pattern is clearly tectonically-induced, but the cause of regional uplift could be linked to climatic cycles. This pattern is associated with a rapid uplift beginning at approximately $900 \mathrm{ka}$, and it may be related to the so called Middle Pleistocene Revolution, characterized by an increase in glacial-interglacial cycles from 41 to $100 \mathrm{ka}$. There are several uncertainties in the extrapolation of explanations for alluvial level formation in regions of cold temperate to warmer climatic zones. However, the cited authors reported that South America has experienced climatic fluctuations similar to those occurring in European areas, in regions exhibiting classic sequences of river terrace formation. Although the action of a comparable mechanism of river level formation appears to be possible, such an explanation has not been determined.

In the case of Conceição River valley, the factor favoring this interpretation is the perfect alternation between levels with sediments cemented by iron oxide-hydroxides (L7, L5, and L3) with those containing uncemented sediments (L8, L6, L4, and L2). The formation of these ferruginous conglomerates appears to reflect a regional climatic phenomenon because similar materials in the same positions are observed in different valleys of Quadrilátero Ferrífero (Cherem et al. 2008, Raposo et al. 2008, Barros \& Magalhäes Jr. 2009, Santos et al. 2009, Barros 2012), as presented in Fig. 10.

Considering the L4 and L3 ages, even though the latter may be overestimated, it seems that both level formations occurred at the last glacial stage, beginning with about $116 \mathrm{ka}$ and ending with $12 \mathrm{ka}$ (Ledru et al. 2009) with the beginning of the early Holocene. However, several climatic oscillations were recorded within this interval (Fig. 11).

The correlation of regional climatic events is difficult due to several factors (Salgado-Labouriau 1997, Thomas 2000). Apart from the margin of error in dating, the identified events can range in age from one location to another for many reasons, for example: stratigraphic position of the collected samples for dating; age difference between the sample material and depositional age; sample contamination; and the inherent errors in the used dating methods. So, climatic phases with precise time limits are hardly established. However, some trends were observed from the available data for Southeastern Brazil, as follows.

Reliable paleoclimate studies reporting periods prior to $50 \mathrm{ka}$ are scarce in continental Southeastern Brazil. 

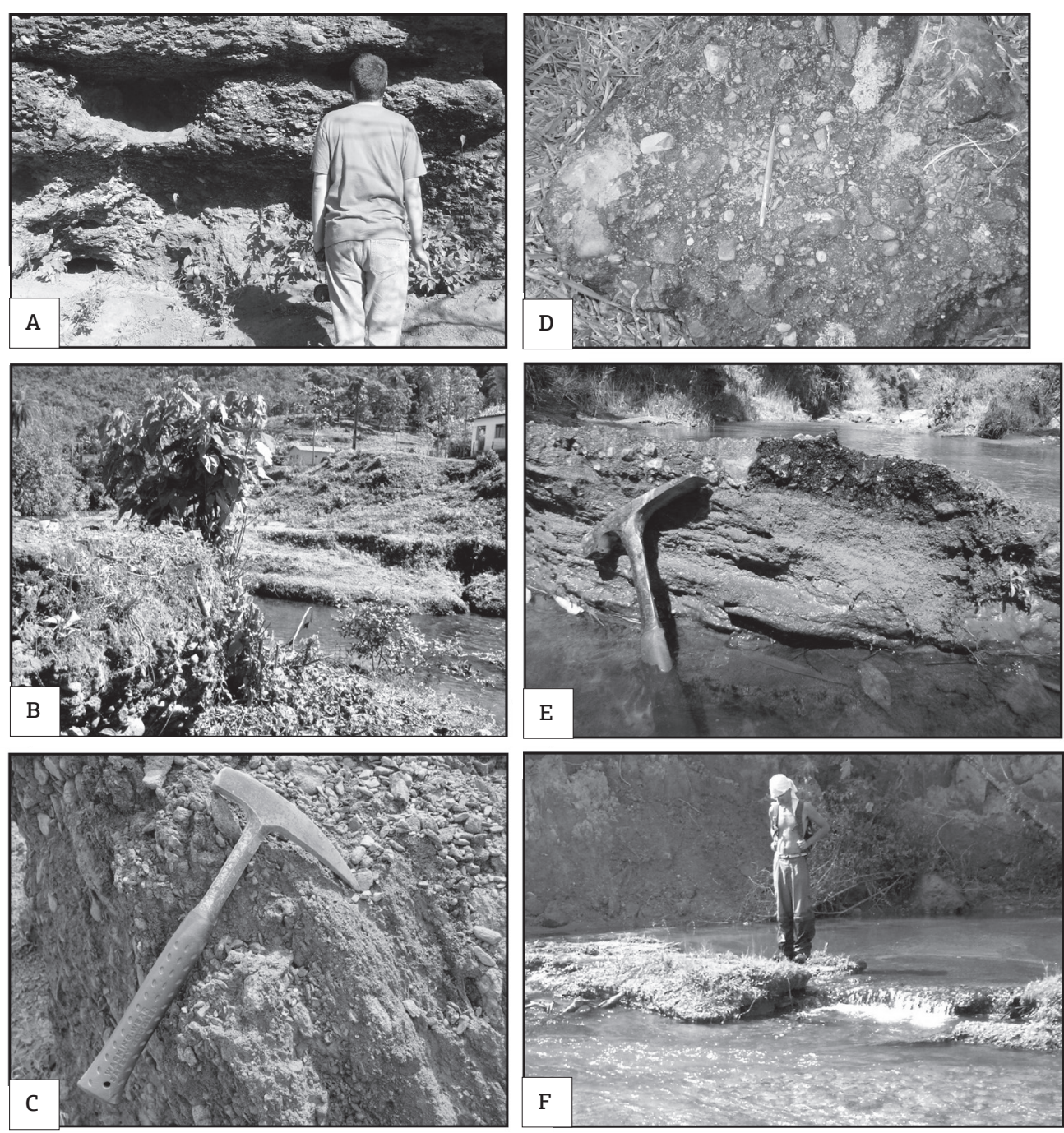

Figure 10. Alluvial deposits with sediments cemented by iron oxides-hydroxides in different valleys of Quadrilátero Ferrífero. Doce River basin: (A) Conceição River valley, (B) Barão de Cocais River valley, (C) Maquiné River valley; Das Velhas River basin: (D) Das Velhas River valley, (E) Maracujá River; (F) Mango River.

From the sedimentary record of Colônia (2352' S, $46^{\circ} 42^{\prime} 20^{\prime \prime}$ W, $\left.900 \mathrm{~m}\right)$, Ledru et al. (2009) noticed that the period between 120 - 106 cal ka BP corresponds to a pollen assemblage of forests with constant moisture adapted to cold and humid conditions. Between 105 - $98 \mathrm{cal} \mathrm{ka}$ BP, these authors observed an increase in arboreal pollen frequency and greater diversity of species, besides a reduction in herbaceous and shrub species. The peak frequency of pollen trees were also observed in Colônia at $\sim 105$ ka by Ledru et al. (2005), and in Santana $\left(24^{\circ} 31^{\prime} \mathrm{S}, 48^{\circ} 43^{\prime} \mathrm{W}\right)$ at $-85 \mathrm{ka}$ by Cruz et al. (2006), representing uniform rainfall with reduced or absent dry season. Considering these events at least as trends of regional climate, it is assumed that the L4 (101 $\pm 9 \mathrm{ka}$ OSL) formation and abandonment would have occurred under a climate that was wetter and colder than the present one.

In the sequence, Ledru et al. (2009) point to dominant rain forest degradation between $89-56 \mathrm{cal}$ ka BP. The pollen assemblage suggests open vegetation with some trees or shrubs, including Araucaria. This scenario is similar to that from Minas Gerais, presented by Ledru et al. (1996) between -50 and $40 \mathrm{ka} \mathrm{BP}$, and by Behling \& Lichte (1997), between -50 and $27 \mathrm{ka} \mathrm{BP}$. These authors discovered evidence of a drier and colder climate than the present one, which would be responsible for grassland dominance and the occurrence of gallery forests, including Araucaria. Starting from the current distribution of Araucaria, Behling \& Lichte (1997) proposed temperatures $5-7^{\circ} \mathrm{C}$ lower for this time than those currently 


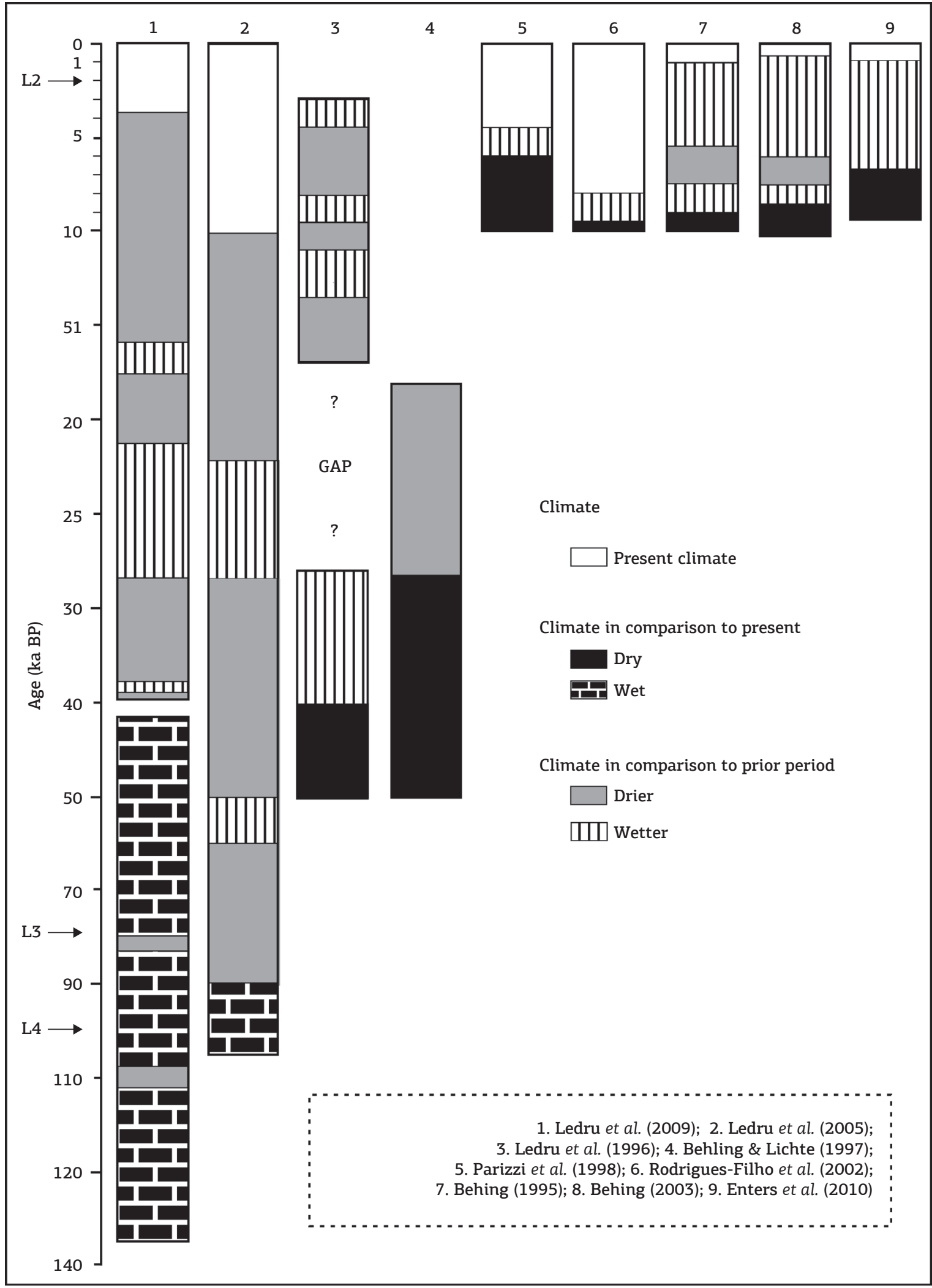

Figure 11. Summary of paleoclimatic periods identified in continental areas of southeastern Brazil. 
observed in the region of Catas Altas. From the analysis of a sedimentary record located a few kilometers southwest of the Conceiçâo River catchment, Gomes et al. (2009) presented a similar dry scenario around $32 \mathrm{ka} \mathrm{BP}$ to the Maracujá River basin, tributary of the Das Velhas River. Therefore, the L3 (77 $\pm 12 \mathrm{ka}$ OSL) formation appears to have occurred under a drier and colder climate than the one of the present. The abandonment of L3 likely occurred with the installation of a wetter climatic regime. According to this assumption, studies that examine pollen records in Minas Gerais indicate a gradual increase in temperature and moisture during the last $10 \mathrm{ka}$ (Behling 1995, Ledru et al. 1996, Parizzi et al. 1998, Rodrigues-Filho et al. 2002, Behling 2003, Enters et al. 2010), suggesting a regional climate behavior.

An extrapolation of these interpretations suggests that the alluvial levels with sediments cemented by iron oxides-hydroxides (L3, L5, and L7) were generated under a drier climate system, while those with uncemented sediments (L2, L4, L6, and L8) are related to a wetter climate regime. The sediment supply to water courses during drier phases would be higher due to minimal vegetation protection and higher concentration in rainfall patterns, resulting in thick riverbed gravel packages. Short rainy periods would raise the water table, being followed by long lowering periods. The coarse grain size would have favored water table oscillation and iron oxide-hydroxide movement due to high hydraulic conductivity, allowing sediment cementation. Moreover, in more humid phases, the protection of slope vegetation would be more present, resulting in the reduction of coarse sediment supply and less fluctuation in water level, which would prevent cementation.

On the other hand, the cyclic formation of river levels with cemented sediments could be related just to a tectonic/structural mechanism. Considering iron abundance, cementation could occur due to a longer water residence time related to base level stability and/or geomorphic thresholds. However, these stability periods should be long enough to allow the cementation of thick sediment packages, but also short enough to prevent intense lateral migration; otherwise, the older levels would not be preserved. This hypothesis does not sufficiently explain why alluvial levels with cemented sediments always have thicker sedimentary packages; however, it is the most plausible explanation for the localized laterite formation in some alluvial profiles such as L8 and L4.

\section{Regional correlation}

In general, the encountered scenario is similar to that found in the middle-upper Paraopeba river catchment
(Marques 1997, Moreira, 1997), with up to five alluvial levels, but there are contrasts in relation to the small number of river levels found in the upper Das Velhas River catchment, which generally contains only three abandoned levels (Magalháes Jr. \& Saadi 1994, Bacellar et al. 2005, Raposo et al. 2008, Magalháes Jr. et al. 2011, Magalháes Jr. et al. 2012).

It is noteworthy that, in the Conceição River valley, the younger terrace (L3), which is in the same level of the modern river, has been dated by OSL in $77 \pm 12$ ka years. However, the oldest fluvial level in the upper Das Velhas River valley (central portion of Quadrilátero Ferrífero), located from 10 to 30 meters above the current river, and completely morphologically uncharacterized, presents maximum ages of $50 \pm 6$ ka years, by dating with the same method (Magalhães Júnior et al. 2011). Similarly, the L5 (located $\sim 15 \mathrm{~m}$ above the current river) was dated in the Conceição River valley in $170 \pm 28$ ka years. Nonetheless, in the middle Das Velhas River basin (just tens of kilometers downstream of Quadrilátero Ferrífero), some ancient alluvial levels, with gaps of approximately $50 \mathrm{~m}$ for the modern drainage, present maximum ages of $167 \pm 18 \mathrm{ka}$ (Magalhães Júnior $e t$ al., in preparation). This framework puts in check both the OSL dating of ancient alluvial sediments in continental tropical context and the understanding about the evolution of regional relief, thus requiring deeper future investigations.

\section{CONCLUSIONS}

The analyses of alluvial records from the Conceiçáo River valley have resulted in the following conclusions:

- Eight river levels were found, including two floodplain levels (L1 and L2), one terrace level (L3), and five morphologically uncharacterized levels (L4, L5, L6, L7, and L8). This scenario is similar to that found in the middle-upper Paraopeba River catchment (Marques 1997, Moreira 1997).

- The predominance of itabirite and hematite gravels in alluvial sequences appears to be connected to the lateral retraction process of the slopes of Quadrilátero Ferrifero. The high erosion rates from the scarp base's weaker lithologies caused the dismantling of itabirites that form the tops of the escarpments.

- The indications of tectonic conditioning in the morphodynamic evolution of the Conceição River valley include river level staircases, and the probable formation of sediment traps, river diversions, and tilting. This geomorphological framework is associated with a rich array of tectonic structures inherited from Precambrian 
geotectonic cycles, which are very important for the neotectonic activity in Southeastern Brazil.

- A probable climatic control is suggested by the cyclic river level formation with cemented iron oxide-hydroxide gravel beds. The occurrence of ferruginous conglomerates in different valleys of Quadrilátero Ferrífero could indicate that this material represents a record of regional climatic events that are correlated to paleobioclimatological events identified in Southeastern Brazil. Further paleoenvironmental investigations will be conducted to reinforce these hypotheses, such as phytolith analysis in the alluvial deposits.

- Some of the ages obtained by OSL are inconsistent with geological and geomorphological contexts. In some cases, the ages may have been underestimated due to the type of sedimentary transport prior to deposition, the presence of colluvium in the samples, or by intense surficial processes. Other ages may have been overestimated due to the presence of accessory minerals and inclusion in quartz grains, in addition to partial bleaching.

The various similarities between the evolution of Conceição River valley and other valleys in Quadrilátero Ferrífero highlight some regional events and conditioning of litho structure, tectonic, climate, and anthropogenic activities. On the other hand, the differences between the obtained ages require more investigation, including the use of different dating methods. However, almost all of the common absolute dating methods have restrictions to be applied in the area due to: scarcity organic matter in the deposits, non-maintenance of the original morphology of several deposits, absence of significant sandy layers, cementation by iron oxides-hydroxides of gravel bed facies etc. Other methods for the correlation of deposits of different valleys are also required, as in the case of ferruginous conglomerate deposits.

\section{ACKNOWLEDGMENTS}

The authors would like to thank Fundação de Amparo à Pesquisa do Estado de Minas Gerais (FAPEMIG), for financial support (Process APQ-00053-09), and Conselho Nacional de Desenvolvimento Científico e Tecnológico (CNPq), for the scholarship concession, and Pró-reitoria de Pesquisa (PRPq) of Universidade Federal de Minas Gerais for the financial support.

\section{REFERENCES}

Alkmim F.F. \& Marshak S. 1998. Transamazonian Orogeny in the Southern São Francisco Craton Region, Minas Gerais, Brazil: evidence for Paleoproterozoic collision and collapse in the Quadrilátero Ferrífero. Precambrian Research, 90:29-58.

Bacellar L.A.P., Coelho Netto A.L., Lacerda, W.A. 2005. Controlling factors of gullying in the Maracujá Catchment, Southeastern Brazil. Earth Surface Processes and Landforms, 30:1369-1385.

Barbosa G.V. \& Rodrigues D.M.S. 1967. Quadrilátero Ferrífero. IGUFMG, Belo Horizonte, Imprensa Universitária, 130 p.

Barros L.F.P. 2012. Eventos sedimentares do quaternário e evolução morfodinâmica do vale do Rio Conceição - Quadrilátero Ferrífero/MG. MS Dissertation, Instituto de Geociências, Universidade Federal de Minas Gerais, Belo Horizonte, 111 pp.

Barros L.F.P. \& Magalhães Júnior A.P. 2009. Paleoambientes Deposicionais Fluviais e Dinâmica Atual do Vale do Rio Maracujá - Quadrilátero Ferrífero/MG. In: ABRH, Simpósio Brasileiro de Recursos Hídricos, 18, Eletronic Proceedings.

Barros L.F.P., Barros P.H.C.A., Magalhães Júnior A.P. 2010. Condicionamento litológico e tectônico na morfometria da bacia do Rio Conceição Quadrilátero Ferrífero/MG. Revista de Geografia (Recife), 1:195-209.

Behling H. 1995. A high resolution Holocene pollen record from Lago do Pires, SE Brazil: vegetation, climate and fire history. Journal of Paleolimnology, 14:253-268.
Behling H. 2003. Late glacial and Holocene vegetation, climate and fire history inferred from Lagoa Nova in the southeastern Brazilian lowland. Vegetation History Archaeobotany, 12:263-270.

Behling H. \& Lichte M. 1997. Evidence of dry and cold climatic conditions at glacial times in tropical southeastern Brazil. Quaternary Research, 48:348-358.

Burbank D.W. \& Anderson R.S. Tectonic Geomorphology. Malden: Blackwell Science, 2001. 274 p.

Bridgland D. \& Westaway R. 2008. Climatically controlled river terrace staircases: A worldwide Quaternary phenomenon. Geomorphology, 98:285-315.

Campos M.I.B. 2006. Caracterização da deformação frágil e sua relação com os processos de voçorocamento na porção sudeste do Complexo Metamórfico Bação - Quadrilátero Ferrífero - Minas Gerais. MS Dissertation, Departamento de Geologia, Universidade Federal de Ouro Preto, 156 p.

Cherem L.F.S., Ramos V.D.V., Lopes F.W.A., Macedo D.R., Magalhães Júnior A.P., Salgado A.A.R. 2008. Níveis e Sequências Deposicionais Fluviais no Médio e Baixo Vale do Ribeirão do Caraça - borda oriental do Quadrilátero Ferrífero/MG. In: UGB, Encontro Latino Americano de Geomorfologia, 2, and Simpósio Nacional de Geomorfologia, 7. Eletronic Proceedings.

CPRM, Companhia de Pesquisa de Recursos Minerais. 2005. Mapa geológico do Brasil ao milionésimo. Rio de Janeiro. 41 CDs, 1 DVD. 
Cruz F.W.J., Burns S.J., Karmann I., Sharp W.D., Vuille M., Ferrari J.A., 2006. A stalagmite record of changes in atmospheric circulation and soil processes in the Brazilian subTropics during the Late Pleistocene. Quaternary Science Reviews, 25:2749-2761.

Dorr J.V.N. \& Barbosa A.L.M. 1963. Geology and ore deposits of the Itabira District, Minas Gerais, Brazil. United States Geological Survey, 110 p. (Professional Paper 341C).

Dorr J.V.N. 1965. Nature and origin of the high grade hematite ores of Minas Gerais, Brazil. Economic Geology, 60:1-46.

Dorr J.V.N. 1969. Physiographic, stratigraphic and structural development of the Quadrilátero Ferrífero, Minas Gerais, Brazil. United States Geological Survey. 110 pp. (Professional Paper 641A).

Enters D., Behling H., Mayr C., Dupont L., Zolitschka B. 2010. Holocene environmental dynamics of south-eastern Brazil recorded in laminated sediments of Lago Aleixo. Journal of Paleolimnology, 44:265-277.

Fabri F.P., Marent B.R., Magalhães Júnior A.P., Salgado A.A.R. 2008. Classificação dos Trechos dos Cursos Fluviais da Bacia do Rio Conceição - Quadrilátero Ferrífero/MG: resultados preliminares. In: UGB, Encontro Latino Americano de Geomorfologia, 2, and Simpósio Nacional de Geomorfologia, 7. Eletronic Proceedings.

Gomes M.O.S., Rodrigues M.F., Delicio M.P. 2009. Evolução paleoclimática e paleoecológica da bacia do Rio Maracujá, Ouro Preto (MG), com base na microflora. In: SBP, Congresso Brasileiro de Paleontologia, 21. Proceedings, $37 \mathrm{p}$

Hartmann L.A., Endo I., Suita M.T.F., Frantz J.C., Carneiro M.A., Mcnaughton N.J., Barley M. 2006. Provenance and age delimitation of Quadrilátero Ferrífero sandstones based on zircon U-Pb isotopes. Journal of South American Earth Sciences, 20:273-285.

Hasui Y. 1990. Neotectônica e tectônica ressurgente no Brasil. In: I Workshop sobre Neotectônica e Sedimentação Continental Cenozóica no SE Brasil. Boletim da Sociedade Brasileira de GeologiaNúcleo Minas Gerais, vol 11, p.1-32.

Jain M., Murray A.S., Botter-Jensen L. 2004. Optically stimulated luminescence dating: How significant is incomplete light exposure in fluvial environments? Quaternaire, 15:143-157.

Kock S., Kramers J.D., Preusser F., Wetzel A. 2009. Dating of Late Pleistocene terrace deposits of the River Rhine using Uranium series and luminescence methods: Potential and limitations. Quaternary Geochronology, 4:363-373.

Lana C.E. \& Castro P.T.A. 2010. Variabilidade morfológica em níveis de base do rio Maracujá (Quadrilátero Ferrífero MG): influências litológicas, estruturais e de reativações cenozóicas. Revista Brasileira de Geomorfologia, 11:21-30.

Ledru M.P., Soares Braga P.I., Soubiè S.F., Fournier M., Martin L., Suguio K., Turcq B. 1996. The last 50,000 years in the Neotropics (Southern Brazil): evolution of vegetation and climate. Palaeogeography Palaeoclimatology, Palaeoecology, 123:239-257.

Ledru M.-P., Rousseau D.-D., Cruz Júnior F.W., Riccomini C., Karmann I., Martin, L. 2005. Paleoclimate changes during the last 100,000 yr from a record in the Brazilian Atlantic rainforest region and interhemispheric comparison. Quaternary Research, 64:444-450.

Ledru M.-P., Mourguiart P., Riccomini C. 2009. Related changes in biodiversity, insolation and climate in the Atlantic rainforest since the last interglacial. Palaeogeography, Palaeoclimatology, Palaeoecology, 271:140-152

Lipski M. 2002. Tectonismo cenozóico no Quadrilátero Ferrífero, Minas Gerais. MS Dissertation, Departamento de Geologia, Universidade Federal de Ouro Preto, 171 p.
Lobato L.M., Baltazar O.F., Reis L.B., Achtschin A.B., Baars F.J., Timbó M.A., Berni G.V., Mendonça B.R.V., Ferreira D.V. Projeto Geologia do Quadrilátero Ferrífero - Integração e Correção Cartográfica em SIG com Nota Explicativa. Belo Horizonte: CODEMIG, 2005.

Magalhães Jr. A.P. \& Saadi A. 1994. Ritmos da dinâmica fluvial NeoCenozóica controlados por soerguimento regional e falhamento: 0 vale do rio das Velhas na Região de Belo Horizonte, Minas Gerais, Brasil. Geonomos, 2:42-54

Magalhães Jr. A.P., Cherem L.F.S., Barros L.F.P., Santos G.B. 2011. OSL dating of sediments from a mountainous river in southeastern Brazil: Late Cenozoic tectonic and climatic implications. Geomorphology. 132:187-194.

Magalhães Jr. A.P., Barros L.F.P., Raposo A.A., Cherem L.F.S. 2012. Dinâmica fluvial quaternária do Rio Maracujá, Quadrilátero Ferrífero (MG). Revista Brasileira de Geomorfologia, 13:3-14

Marques M.R. 1997. Morfodinâmica fluvial cenozóica no vale do Rio Paraopeba entre o Fecho do Funil e Juatuba, Minas Gerais. MS Dissertation, Instituto de Geociências, Universidade Federal de Minas gerais, $91 \mathrm{p}$.

Martins M.L. 1994. Mineração, agricultura e degradação ambiental em Minas Gerais nos séculos XVIII e XIX. LPH: Revista de História, 4:14 p.

Maxwell C.H. 1972. Geology and ore deposits of the Alegria district, Minas Gerais, Brazil. Washington, U.S. Government Printing Office, 72 p.

Medina A., Dantas M.E., Saadi A. 2005. Geomorfologia. In: Projeto APA Sul RMBH - Estudos do Meio Físico. Belo Horizonte: CPRM/ SEMAD/CEMIG, v. 6.

Mello C.L. 1997. Sedimentação e tectônica cenozóicas no Médio Vale do Rio Doce (MG, sudeste do Brasil) e suas implicações na evolução de um sistema de lagos. PhD Thesis, Instituto de Geociências, Universidade de São Paulo, São Paulo, 275 p.

Moreira P.F. 1997. Depósitos cenozóicos e evolucão morfodinâmica na bacia do Ribeirão Serra Azul (médio Rio Paraopeba), Minas Gerais. MS Dissertation, Instituto de Geociências, Universidade Federal de Minas gerais, $111 \mathrm{p}$

Murray A.S. \& Olley J.M. 2002. Precision and accuracy in the optically stimulated luminescence dating of sedimentary quartz: a status review. Geochronometria, 21:1-16

Parizzi M.G., Salgado-Labouriau M.L., Kholer H.C. 1998. Genesis and environmental history of Lagoa Santa, southeastern Brazil. The Holocene, 8:311-321.

Parra R.R. 2006. Análise geoquímica de água e de sedimentos afetados por minerações na bacia hidrográfica do Rio Conceição, Quadrilátero Ferrífero, Minas Gerais - Brasil. MS Dissertation, Departamento de Geologia, Universidade Federal de Ouro Preto, $113 \mathrm{p}$

Raposo A.A., Oliveira L.F., Magalhães Júnior A.P., Cherem L.F.S. 2008. Níveis e sequências deposicionais do vale do ribeirão do Mango, Quadrilátero Ferrífero/MG. In: UGB, Encontro Latino Americano de Geomorfologia, 2, and Simpósio Nacional de Geomorfologia, 7 Eletronic Proceedings.

Riccomini C. 1989. O Rift Continental do Sudeste do Brasil. PhD Thesis, Instituto de Geociências, Universidade de São Paulo, São Paulo.

Rodrigues-Filho S., Behling H., Irion G., Müller G. 2002. Evidence for lake formation as a response to an inferred Holocene climatic transition in Brazil. Quaternary Research, 57:131-137.

Saadi A. 1991. Ensaio sobre a morfotectônica de Minas Gerais: tensões intra-placa, descontinuidades crustais e morfogênese. PhD Thesis, Instituto de Geociências, Universidade Federal de Minas Gerais, Belo Horizonte. 
Saadi A. 1993. Neotectônica da Plataforma Brasileira: esboço e interpretação preliminares. Geonomos, 1:1-15.

Saadi A., Bezerra F.H.R., Costa R.D., Igreja H.L.S., Franzinelli E. 2005. Neotectônica da Plataforma Brasileira. In: Souza C.R.G., Suguio K., Oliveira M.A.S., Oliveira P.E. (eds.) Quaternário do Brasil. Ribeirão Preto, Holos, p. 211-234.

Salgado A.A.R., Varajão C.A.C., Colin F., Braucher R., Varajão A.F.D.C., Nalini Júnior H.A. 2007. Study of the erosion rates in the upper Maracujá Basin (Quadrilátero Ferrífero/MG, Brazil) by the in situ produced cosmogenic ${ }^{10} \mathrm{Be}$ method. Earth Surface Processes Landforms, 32:905-911.

Salgado-Labouriau M.L. 1997. Late Quaternary palaeoclimate in the savannas of South America. Journal of Quaternary Science, 12:371-379.

Sallun A.E.M. \& Suguio K. 2007. Datação absoluta por luminescência do Alogrupo Alto Rio Paraná (SP, PR E MS). Revista do Instituto Geológico, 27-28:13-29.

Salvador E.D. 1994. Análise tectônica do vale do Rio Paraíba do Sul compreendida entre Cruzeiro (SP) e Itatiaia (RJ). MS Dissertation, Instituto de Geociências, Universidade de São Paulo, São Paulo.

Sant'Anna L.G., Schorscher H.D., Riccomini C. 1997. Cenozoic Tectonics of the Fonseca Basin Region, Eastern Quadrilátero Ferrífero, MG, Brazil. Journal of South American Earth Science, 10:275-284

Santos G.B., Magalhães Júnior A.P., Cherem L.F.S. 2009. Níveis de terraços fluviais e depósitos sedimentares correlativos no alto vale do Rio das Velhas, Quadrilátero Ferrífero, MG. Revista Brasileira de Geomorfologia, 10:73-84

Sarges R.R. 2002. Morfologia de lagos da região médio vale do rio Doce, Minas Gerais, e sua relação com a tectônica quaternária. MS Dissertation, Universidade Federal do Rio de Janeiro, Rio de Janeiro, 188 p.

Silva T.P. \& Mello C.L. 2011. Reativações Neotectônicas na Zona de Cisalhamento do Rio Paraíba do Sul (Sudeste do Brasil). Geologia USP, Série científica, 11:95-111.
Sommé J. 1990. Enregistrements: reponses des environnements sedimentaires et stratigraphie du Quaternaire - exemples D Achenhéim (Alsace) et de La Grande Pile (Vosges). Quaternaire, 1:25-32.

Souza C.J.O. 1995. Interpretação morfotectônica da bacia do Rio Doce. MS Dissertation, Instituto de Geociências, Universidade Federal de Minas Gerais, Belo Horizonte, 146 p.

Stevaux J.C. 2000. Climatic events during the Late Pleistocene and Holocene in the upper Parana River: correlation with NE Argentina and South-Central Brazil. Quaternary International, 72:73-85.

Suguio K. \& Kohler H.C. 1992. Quaternary barred lake systems of the Doce River (Brazil). Anais da Academia Brasileira de Ciências, 64:183-191.

Tatumi S.H., Peixoto M.N.O., Moura J.R.S., Mello C.L., Carmo I.O., Kowata E.A., Yee M., Brito S.L.M., Gozzi G., Kassab L.R.P. 2003. Optical dating using feldspar from Quaternary alluvial and colluvial sediments from SE Brazilian Plateau, Brazil. Journal of Luminescence, 102:566-570.

Tatumi S.H., Gozzi G., Yee M., Oliveira V.I., Sallun A.E.M., Suguio K. 2006. Luminescence dating of quaternary deposits in geology in Brazil. Radiation Protection Dosimetry, 119:462-469.

Thomas M.F. 2000. Late Quaternary environmental changes and the alluvial record in humid tropical environments. Quaternary International, 72:23-36.

Valadão R.C. \& Silveira J.S. 1992. Estratigrafia Quaternária e evolução do Relevo no Complexo do Bação, Dados Preliminares. Revista Escola de Minas, 45:85-87.

Varajão C.A.C., Salgado A.A.R., Varajão A.F.D.C., Braucher R., Colin F., Nalini Júnior H.A. 2009. Estudo da evolução da paisagem do Quadrilátero Ferrífero (Minas Gerais, Brasil) por meio da mensuração das taxas de erosão $\left({ }^{10} \mathrm{Be}\right)$ e da pedogênese. Revista Brasileira de Ciência do Solo, 33:1409-1425.

Arquivo digital disponível on-line no site www.sbgeo.org.br 